УДК 792.091.5/.6(497.11)”.../1870

https://doi.org/10.18485/msc50.2019.1.ch18

Божидар Ковачек

\title{
НАРОДНА КЊИЖЕВНОСТ И РЕПЕРТОАР СТАЛНИХ СРПСКИХ НАРОДНИХ ПОЗОРИШТА ДО 1870.
}

Оснивање првих сталних, професионалних, народних позоришта код Срба (Нови Сад, 1861; Београд, 1868) имало је своју дугу предисторију. Школска позоришта, аматерске групе, путујући ансамбли множили су се у XIX веку све више, како је време одмицало. У читавом томе веома распрострањеном раду чисто уметнички разлози и побуде преплићу се понекад са комерцијалним, али много чешће, готово по правилу, са националним. Основни подстицај за рад на позоришту лежи у потреби формирања и снажења српске нације у тада модерном, буржоаском смислу. И са̂мо оснивање Српског народног позоришта то потврђује. Оно се сматра конститутивним елементом српске нације, оно треба да буде израз једне друштвене снаге која је у апсолутизму сазревала, а после њега се учврстила као нови, национални и напредни ослонац општенародних српских кретања у Угарској. Јован Ђорђевић, оснивач позоришта, то је овако формулисао: „Овде се не ради о приватној забави једне вароши, о личним интересима неколико људи. Овде је говор о вишим духовним интересима народа, о народној свести, народном поносу и карактеру, о народном језику и литератури, једном речи о ономе, што је народу најмилије и најсветије. Народно позориште све ово чува, негује, облагорођава”. Оснивање позоришта у Београду употпуњује организацију Србије као државе; оно је један од атрибута националности и независности.

Разумљиво је да овакво позориште, са првенствено мисионарсконационалним задацима, са одређеном политичком функцијом, у репертоарском погледу остаје доследно својој мисији, колико год то дозвољава релативно нејака тадашња драмска литература. Стога репертоар у првој деценији апсорбује из дотадашње домаће драмске књижевности све што има националне одлике, чак и без обзира на уметничке домете и вредности. Артистичка страна позоришта, литерарна вредност текстова, свесно се подређују националним императивима. То је, уосталом, и захтев пу- 
блике, коју чини, претежним делом, још млада српска грађанска класа, жељна своје националне афирмације. У којој мери захтеви средине иду ка делима експлицитне и националистичке оријентације, могу да покажу неки чисто бројчани подаци: У новосадском позоришту до краја 1870. изведена су 43 домаћа драмска дела. Од тога је 33 са историјском или псеудоисторијском потком, условно речено националних историјских драма, а свега десет комедија домаћих писаца. У београдском позоришту је слично, у периоду 1868-1870 било је на репертоару 29 домаћих историјских драма, пет комедија и два дела која се не сврставају у ове категорије. Овај однос од приближно пет према један у корист историјске драме још се и повећава када се утврди број представа једне и друге групе. Просечан број реприза за комедије је осам, а за историјске драме седамнаест, дакле двоструко већи. Тај однос видљив је и код дела појединих писаца. Носилац националног репертоара био је Јован Стерија Поповић. У првој години рада Српског народног позоришта изведено је по пет његових комедија и историјских драма. Данас нема никакве двојбе у оцени да су Стеријине комедије у односу на драме у огромној предности по својој вредности. Публика из времена оснивања позоришта мисли, међутим, друкчије. Просечан број представа стоји у односу два према један за историјску драму. Највише тражено његово дело било је Сан Кральевића Марка које је доживело 42 извођења за десет година, док је највише гледана комедија, Тврдица или Кир Јағьа имала у истом периоду свега 12 извођења. Осим о неразвијеном укусу тадашње публике, ове цифре јасно сведоче и о друштвеном захтеву који се позоришту поставља.

Репертоар који толико форсира историјске теме диктирао је и оријентацију писаца. Знајући да историјске драме имају двоструко већу шансу да буду приказане, писци овога периода, па и доцнији, посежу радо за историјским темама. Међу њима су и тако истакнута имена као што су Ђура Јакшић и Лаза Костић.

Природан ослонац историјским драмама писци трже и налазе у народној поезији. Још од самог почетка XIX века народна поезија је кохезиона снага нације, не само по томе што доприноси језичкој унификацији, него и по израженом националном и слободарском духу. По неким новијим оценама, народна поезија је ближа романтичарским стремљењима него уметничка књижевност код Срба с почетка XIX века. Емотивност и машта све су присутнији у збиркама народне поезије, унутрашња драматика све више потискује хроничарски тон, евокације прошлости су основна тематска преокуапција, ликови епских песама по правилу су изузетне, често сасвим хиперболисане личности. Уметничкој литератури која је блиска романтичарским схватањима или њима тежи, народна 
Народна книжевност и репертоар сталних српских народних позоришта... 207

поезија може да пружи далеко више него уметничка књижевност доба просвећености. Поред тематике, народна књижевност нуди писцима формиран језик постављен на природне основе, нуди уобличен стил, нарочито у погледу версификације. Што је најважније, у народној поезији је садржана готово систематизована национална митологија у којој се поједини елементи већ уобличују у симболе.

Драмски писци, већ од првих деценија XIX века, много више се опредељују за народну традицију као инспирационо врело, него што то чине писци у другим литературама. Готово да се може рећи да је драмска књижевност српскохрватског језика у XIX веку по тој својој оријентацији јединствена међу светским литературама новог доба.

Ваља имати на уму да је српска историографија, све до последње четвртине XIX века, потпуно подређена традиционалним схватањима прошлости, нарочито средњевековља. Почевши већ са XV веком (Константин Филозоф), а нарочито у XVII веку (Пајсије) и XVIII (Троношки родослов) историографија све више упија елементе народне традиције. У њој се историјска истина веома тешко одлучује од легендарнога. Упркос покушајима просвећености, народна традиција и у XIX веку остаје битан елеменат историографије. Шта више, романтичарска школа у историографији везује се за народну поезију као историјски извор намерно и организовано, сматрајући, с правом, да потребама општенародне борбе за ослобођење и уједињење одговара реконструкција прошлости препуна идеализација. Тако ће бити све до последње четвртине XIX века, када критичка историографија модерним научним аргументима наноси тежак пораз традиционализму у историји.

То значи да драмски писци, тражећи грађу за своја дела у сувременој историографији, њеним посредством ипак долазе до духа народне поезије, па чак и до грађе преузете из традиције и легенде. Песнички награђујући овакву „чињеничку” и „рационалну” окосницу, драмски писци иду још ближе духу народне поезије, јер се општа историјска свест свих Срба ХІХ века формира управо у том духу.

Када се има у виду овакво стање свести и схватање историје, долазимо до четири основна правца утицаја народне књижевности на драмску литературу са репертоара првих српских позоришних кућа.

А. Директна позајмииа теме из народне поезије. Мада оваквих случајева има релативно мало, они су посебно занимљиви зато што је ту утицај народне поезије сасвим непосредан, заправо генетски, и зато што су ово примери трансформације једне теме и фабуле из једног у други књижевни род. Одређен и јединствен стваралачки поступак код ове групе драма не може се успоставити. Наиме, драме настале „по народ- 
ној песми” разликују се веома и по развијености, и по уметничкој вредности, и по драмском типу. Крећу се од готово безвредних позоришних игара Атанасија Николића, до Максима Црнојевића Лазе Костића, дела које стоји у самом врху драмске књижевности романтичарског доба. По драмској типологији различите су - од мелодраме, чак оперете, до трагедије. Атанасије Николић у Зидағу Раванище или у „јуначкој игри” Краљевић Марко и Арапин народне епске песме схвата као готов либрето за оперету и мелодраму. Гледано по књижевној вредности његово дело је далеко испод народне песме по којој је рађено. Лаза Костић, међутим, мада фабула песме Женидба Максима Црнојевића у извесној мери следи, једноставне и једностране крокије ликова народне песме развија у драмске, трагичне, шекспировске карактере, радњу мења и заобљава многим домишљеним елементима, драматику песме доводи до трагичног патоса, емотивност песме доводи до судбинских страсти и до лиричности профињене и изузетно сугестивне. Између једнога и другога пола - Николића и Костића - стоје остали покушаји. Свима им је полазна тачка иста: појединачна народна епска песма.

Б. Историјске теме рађене у духу народне поезије. Ово је највећа група драма са репертоара 1861-1870. Њихова веза са народном поезијом је најчешће успостављена преко историјских личности које су уједно и хероји народне поезије. Већи број драма ове групе чине дела тематски везана за битку на Косову, дакле и за косовски циклус народних песама. Све без разлике следе легенду која је о косовском боју формирана у традицији о доласку Турака. У свима њима то је време коначног слома средњевековне славе, тренутак потпуне пропасти. Историја је већ шездесетих година била исказала извесне сумње у тачност косовске легенде. Тада већ, историја је јасно знала да је тренутак коначне пропасти средњевековне Србије уследио тек после пада Смедерева (1459). Писци драма све ово заобилазе, чак и када су људи од науке какав је био Јован Стерија Поповић. Његова драма Милош Обилић, и поред покушаја европеизације, чак шекспиризације, садржи све компоненте косовске легенде, чак су у њој и она лица која су позната само народној песми а не и историји. Исто је и са драмом Милош Обилић Јована Суботића. Мада у извесној мери критичан према легенди, Суботић се не одмиче од концепције Косова коју је предање донело; он само покушава да премости нелогичности и недоречености које легенда оставља отвореним. Без сумње је да су оба писца знала да се историја и народна поезија не поклапају. Ипак, опредељују се за народну традицију, из истог разлога као и романтичарска историографија. То је „pia fraus” национализма онога времена. Друкчије није ни могло бити. Када је Матија Бан у драми Цар Лазар покушао да 
лик Марка Краљевића уобличи према историји, дакле без херојског ореола, уплео се у опасну јавну полемику, а представа драме није доживела репризу. Публика и јавност нису хтели такву драму. Она се није репризирала ни када је 1887. стављена на сцену Српског народног позоришта, иако је тада критичка историографија већ увелико осветлила истину о средњевековној прошлости.

В. Угледане на форму народне поезије. Народна књижевност имала је пресудан удео у језичкој реформи српске књижевности, која започиње у другој деценији XIX века а победоносно се окончава тек неколико година после Вукове смрти. Језик народне књижевности магнетично је привлачио романтичаре, нарочито „прекосавске”, чији родни говор није ни близу чистоти и мелодиозности Вукове ијекавице. Заједно са језиком, превагу у романтичарској поезији има и народни стих, првенствено десетерац. Употребљавају га скоро сви писци чије драме видимо у репертоару до 1870: Стерија, Суботић, Бан, Атанасије Николић, Јован Драгашевић, Ђура Јакшић, Лаза Костић. Најчешће, код њих је десетерац трохејски, или трохејске тенденције, као у народној поезији, али се користи и јамб. Опредељеност за десетерац има, међутим, различите резултате. Стихови Атанасија Николића у својој тривијалности безмало пародирају народну епику, док патетични јамбски десетерац Лазе Костића доказује изванредно плодотворне могућности варирања овога народног стиха.

Веома је занимљива и знатна стилска подударност историјских драма романтичарског периода и народне епике. Народна песма често о догађајима прича описујући их живим говором учесника. Овај манир преузела је и историјска драма, на своју велику штету. И у њој се више прича о догађајима но што се они виде на сцени, а то у позоришту никако не може бити добро. Епска понављања такође су се помало увукла у драму, а није им тамо место. Епитети, метафоре, хиперболе и други стилски накит карактеристичан за народну поезију присутан је у драми у веома сличним варијететима.

Г. Уношене народних песама у текст драме. Ни ова појава, која се односи углавном на лирску народну поезију, није зачета у периоду о коме овде говоримо, него знатно раније. Године 1812. давао се у Пешти комад Иштвана Балога Црни Ђорђе или Освајане Београда од Турака. Представа је била мађарска, а у комаду је играла, тада сасвим млада, потоња велика мађарска глумица Дерине Сепатаки Роза. У својим успоменама („Déryné Naplója”) она каже: „Играла сам у њему (комаду) Ружицу, малу српску девојку, и певала сам једну арију и један дует - на српском језику. Прва (песма) је била тужна и текст је овако гласио: 
Што ми фајда од младости

Кад пребивам у жалости,

Што не могу с драгим бити

Ни у дане ни у ноћи.

Дует је био једна доиста мила, праскава песмица коју је певала девојка заједно са својим драгим и гласила је:

Дивојчице! дивојчице!

Ружа румена

Ак не смидем од мог брата

Душа рођена.

Било је славе, било је бурних аплауза каквих до тада нисам била никад добила, ни ја нити ико други. После сваке песме понављања и изазивања толико да је већ много било. Онда још у Пешти је становало заиста много Срба".

Судећи по текстовима (иако их мађарска глумица изгледа није баш тачно упамтила) ово су песме усмене провенијенције, блиске народним, нарочито друга.

Поступак да се на позорници певају народне лирске песме нарочито се уобичајио одомаћивањем на репертоару такозваних „народних комада са певањем". Када текстови који су се певали и нису били изворно народни, они су били писани „на народну”, имитирањем лирске народне песме. Овај обичај био је толико устаљен да су чак и преводи страних комада, односно прераде и посрбе, често добијали за саставне делове наше народне песме уместо превода изворних стихова. Само један пример. Поправљајући превод Радивоја Стратимировића Сиглигетијеве драме Војнички бегунаи, Јован Ђорђевић је 1863. године замолио Јована Јовановића Змаја да изнова преведе песме. Змај је то учинио, али је један Сиглигетијев текст оставио замењеним народном жетелачком песмом „Јарко сунце одскочило”. Даља истраживања показаће тачније колики је утицај имала на драме лирска народна песма, али је несумњиво да он није био мали.

Ови основни правци утицаја народне књижевности на драмски репертоар нису и једини. Ваља поменути, на пример, Змајевог Шарана који основну потку има у народној прози. Мноштво реминисценција и асоцијација у текстовима драма које немају директније тематске везе с народном књижевношћу потичу ипак из ње, јер су уткане у свест писаца и публике - најчешћа су у овом смислу поређења са личностима из народне традиције. У општем изражајном склопу драмске литературе видљиви су трагови фразеологије својствене народној књижевности - 
непребројиве су, на пример, пословице којима писци богате језик својих драмских ликова. Сличних додира има веома много већ на први поглед и они су увек посредан доказ ослањања драмске литературе на духовни сустав народне књижевности и традиције.

Нема, дакле, никакве сумње да је утицај народне књижевности на српску романтичарску драму био веома снажан. Такве димензије тога утицаја ипак је тешко одредити без подробних испитивања, не на једном ограниченом узорку како сам ја овде покушао, него на целокупној драмској оставштини романтизма. Не сумњам да би резултати могли бити веома инструктивни за историју српске књижевности, а контрастивно постављени и за типологију романтизма уопште.

\section{Božidar Kovaček}

\section{„NARODNA KNIIŽEVNOST” UND DRAMEN AUS DEM REPERTOIRE DER STÄNDIGEN SERBISCHEN THEATER IM 1. JAHRZEHNT IHRER TÄTIGKEIT}

\section{Zusammenfassung}

Die Gründung der ständigen serbischen professionellen Theater (Novi Sad 1861, Beograd 1868) ist eine Forderung vor allem nationaler und erst danach künstlerischer Belange. Ihr Repertoire bis 1870 bestätigt das sehr überzeugend. Aus der vorhandenen dramatischen Literatur in serbokroatischer Sprache wird für das Bühnenrepertoire all das ausgewählt, was eine nationale Färbung besitzt, ohne besondere Rücksicht auf den künstlerischen Wert. Das Publikum ist der historischen bzw. pseudohistorischen Thematik ausserordentlich zugetan. Die Dramenschriftsteller setzen sich bereits in den ersten Jahrzehnten des 19. Jahrhunderts sehr viel mehr für die Volkspoesie als Quelle der Inspiration ein als die Schriftsteller in anderen europäischen Literaturen. Auch daher ist die Typologie der serbischen Dramenliteratur der Romantik völlig einzigartig. Erkennbar sind vier Hauptrichtungen des Einflusses der „Narodna književnost” auf das Dramenrepertoir der untersuchten Periode:

1. direkte Entlehnung von Themen aus der „narodna književnost”

2. Bearbeitung historischer Themen im Sinne und nach der „Faktografie” der Volkspoesie

3. Anlehnung an die Form der Volkspoesie

4. Einbringen von Volksliedern in den Text des Dramas. 